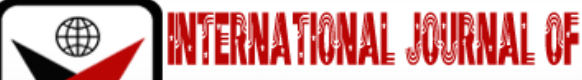

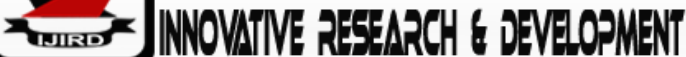

ISSN 2278-0211 (Online)

\section{If Aristotle Had Not Been a Student of Plato, He Would Have Founded the Lyceum: A Critical Evaluation of the Dilemma of Counterfactuals of Creaturely Freedom}

\author{
Venerable Blessed Nyemobuchi Orji \\ Ph.D. Student Department of Religious and Cultural Studies, \\ University of Port Harcourt, Rivers State, Nigeria
}

\begin{abstract}
:
The problem of counterfactuals of creaturely freedom is a perennial one. Counterfactuals of freedom presuppose that what is now could have been different if a different state of affairs were to obtain. But there are some objections to the plausibility of counterfactuals of creaturely freedom. There is the Biblical, theological and philosophical objection. Further, there is the argument that counterfactual knowledge places God's knowledge at the determination of the agent's free action via His free knowledge. This again, poses a problem to philosophers. There is also the problem of determinism, which some have argued, is entailed by counterfactual knowledge. The idea here is that if God knows all the possible or metaphysical worlds that can be and creates or allows a set of circumstances in which the individual could act according to His purpose, then, to say that the individual is free to act otherwise, is to say the least, an illusion. These problems and many others form the fulcrum of this study. The study is anchored on the middle knowledge theory developed with great ingenuity by the Jesuit priest, Luis de Molina. The study upholds the view that God has exhaustive knowledge which encompasses those of counterfactuals of creaturely freedom and that He exercises providential control through His middle knowledge while not violating the freedom of the will.
\end{abstract}

Keywords: Counterfactuals, middle knowledge, foreknowledge, Aristotle, Plato

\section{Introduction}

The problem of counterfactuals of creaturely freedom is an age long controversy. Counterfactuals of freedom presuppose that what is now could have been different if a different state of affairs were to obtain. But there are some objections to the plausibility of counterfactual of creaturely freedom. There is the Biblical, theological and philosophical objection. The Biblical objection evaluates the Biblical fidelity of counterfactuals which is unique to Molinism and known as middle knowledge and claims that Counterfactuals have no Biblical grounding while the argument from a theological perspective holds that the exegetical and hermeneutical enterprise reveal quite succinctly that counterfactuals of freedom are false. The most prominent objection to Molinism is the 'grounding objection' which argues that counterfactuals of freedom lack metaphysical grounds and therefore cannot be true or false, meaning that God cannot know them. This is why the critics of counterfactuals of creaturely freedom have argued that the only plausible metaphysical grounding of counterfactuals is the intentions, desires and character of the person mentioned in the counterfactual. Further, counterfactual knowledge places God's knowledge at the determination of the agent's free action via His free knowledge. This again, poses a problem to philosophers. For many argue that God's knowledge cannot be determined by anything which is extrinsic to Him, and which would not be caused by Him. But the position of the proponents of counterfactuals or middle knowledge is that God's knowledge depends on the determination of the free conditional future and this determination does not come from God but from the liberty of agents when placed in certain circumstances.

There is also the problem of determinism, which some have argued, is entailed by counterfactual knowledge. The idea here is that if God knows all the possible or metaphysical worlds that can be and creates or allows a set of circumstances in which the individual could act according to His purpose, then, to say that the individual is free to act otherwise, is to say the least, an illusion. These problems and many others form the fulcrum of this study.

\section{Conceptual Clarifications}

The main concepts that form our study are counterfactuals and freedom. Let us begin with a brief look at counterfactuals. Counterfactuals are propositions which indicate what effects, 'would in fact be produced, remotely or immediately, by indeterministic secondary causes under a condition or hypothesis that specifies a possible spatio temporal arrangement of secondary causes (Freddoso, 1988). They refer to those states of affairs that would obtain if the situation were different from what it is. A glaring example is the one found in our topic of discourse. That is, 'If Aristotle were not a student of Plato, he would have still founded the Lyceum.'Aristotle (born in 384BC) was a student of Plato in 
the Academy founded by the latter.Aristotle was his most brilliant student and he studied under Plato for over twenty years (Omoregbe, 2011a:65). But his line of thinking, temperament and philosophy differed from those of his teacher. While Plato had persuasion for rational speculation, Aristotle was inclined towards empirical research. For Plato, objects of knowledge are not the material things in this world, but the Forms in the world of Forms, the supra - sensible world which is the real world. The material world is the world of appearance and only gives us illusion. But the world of Forms gives us real knowledge. While Plato opined that man was born with innate ideas and so knowledge is only the product of reminiscence or recollection, Aristotle held that all ideas come from sense perception and are circumscribed in sense perception. Therefore, for Aristotle, there was nothing in the intellect that was not first in the senses.

Aristotle studied under Plato until Plato's death in 347 BC. And upon the latter's death, he left the Academy and founded his own school known as the 'Lyceum.'In the Academy, courses like rhetoric, mathematics, astronomy, history, politics, etc.were taught. The Academy had several challenges arising from change of leadership. Whenever the Academy was manned by the Skeptics, skepticism became the dominant doctrine of the Academy and so on. In the Lyceum, biology and physics were taught in addition to the subjects taught in the Academy. Now the poser is, 'If Aristotle was not a student of Plato, would he have founded the Lyceum?' Counterfactuals of freedom maintain that God has knowledge of all the metaphysical states of affairs including what Aristotle would have done if he were not a student of Plato.

Another concept in our study which is of importance to us is freedom. Freedom has been conceived differently by different scholars. To some scholars, freedom is a delusion because, according to them, we live in determined world that is governed by inexorable laws of nature and antecedent events. To others, freedom is required for moral responsibility and our laws, customs and courts are formed and established with a belief in the ability of the individual to choose between good and evil. According to Omoregbe (2011b), freedom is the capacity for self-consciousness. For Uduigwomen and Ozumba (2005), freedom entails the presence of alternatives, the rationality of the agent and the absence of constraints. In other words, these things are required for a person to be said to have acted freely.

\section{Theoretical Framework}

The theory that undergirds this study is the middle knowledge theory which is known in Latin as Scientia Media.To some philosophers and theologians, God possesses middle foreknowledge. Their view is that God knows not only what would happen in the actual world or what could in fact happen in all possible worlds but also what would in fact happen in all possible situations, including what every possible free creature in every possible situation in which that creature could find itself would do (Basinger, 2014:284). The theory was called middle knowledge by the Jesuits because they thought it had a middle status between other kinds of knowledge-between God's knowledge of the merely possible and his knowledge of the actual; or between his knowledge of necessary truths, which all follow from the divine nature, and his knowledge of his own will and everything that is causally determined by His will (Adams, 2014:290). Simply put, the theory takes a middle ground between the more extreme positions of Calvinism and open theism (Vanarragon, 2010:67). According to Internet Encyclopedia of Philosophy, the term is called middle knowledge because it stands in the middle of the two categories of divine epistemology as handed down by Aquinas; that is, natural and free knowledge.It shares in the characteristics of both and, in the logical order of the divine deliberative process regarding creation, it follows natural knowledge but precedes free knowledge. The theory was developed with great ingenuity by Luis de Molina (1535-1600), a Spanish Jesuit priest, and defended by other notable Jesuit theologians including Francisco Suarez. It was in response to the great controversy which erupted between the Jesuits and the Dominicans about the relations between God's grace and human freewill. The Jesuits held among other things, that many human actions are free in the sense that their agents are not logically or causally determined to do them (Adams 2014:290). God, therefore, does not control human history by causally determining human actions, as the Dominicans seemed to contend, but controls human actions by causing circumstances in which the individual would freely act according to His will.

The notion of middle knowledge is that God with middle foreknowledge knew before creation what would in fact eventuate, given every option open to Him. This does not necessarily mean the ability to actualize the most desirable state of affairs of which He could conceive. He may have desired to create a world containing individuals with indeterministic freedom and even God, as already conceived, cannot control all of the activities which go on in such a world. But the fact that He knew beforehand what would eventually happen given any creative option does, of course, mean that no conjecture or gambling was involved in the creative process. God did not have to worry about any surprises and He knew no second guessing would be necessary. For He had the ability to consider all actualizable worlds and choose the one which best represented His created options. The implication of middle foreknowledge is that since God knows all that would happen in the actual world, He can make infallible public prophetic claims or proclamations about future states of affairs. He can go further to make accurate conditional prophecies which involve human choices and decisions. In this instance, He can say exactly what would happen if certain decisions are made and what would happen if they are not. This is because He sees both possibilities with equal clarity and precision. Acting in this capacity He knows that Blessed N. Orji would be a clergyman. He also knows what would have happened if he chose not to be a clergyman. He knows with precision if the choice to be a clergyman was the best option or not.

The middle foreknowledge theory has been severely criticized. It is argued that if the hypothetical conditionals of freedom were true, God would have knowledge of them. But some philosophers deny that those conditionals ever were or ever would be true. In the same way, Adams (2014:290) rejects the idea of middle knowledge on grounds that that conditional knowledge of the sort that is supposed to be known by middle knowledge cannot be true. Further, he maintains that it is very difficult to refute someone who claims to have a primitive understanding which he seemed not to have. In what follows, we shall consider the two kinds of knowledge from where middle knowledge shares its characteristics. 


\section{Natural and Free Knowledge}

Natural knowledge is that part of God's knowledge which He knows by His very nature and essence, and since His essence is necessary so is that which is known through it (Internet Encyclopedia of Philosophy). It is that part of God's knowledge which could not have been different from what it is, and hence, independent of God's will and decision. This is why it is held that God has no control of the truth of propositions that He knows by natural knowledge. And because natural knowledge is independent from God's will, and to some extent places limits upon the things God can do, natural knowledge informs God's decisions regarding His creative work. Hence, natural knowledge is prevolitional (Internet Encyclopedia of Philosophy). Examples are mathematical truths or propositions, all possibilities and tautologies. Let us begin with mathematical truths. A typical example is $2+2=4$. In this instance, there is nothing God can do to change the fact that $2+2=4$; for $2+2=4$ cannot not be $2+2=4$. That is, if p----q, p....-p, no matter what happens. An example of tautology is 'A bachelor is an unmarried man.' This tautology cannot not be true and there is nothing anyone can do to invalidate the truth of the assertion. In a nutshell, the content of natural knowledge includes all metaphysically necessary truths.

On the other hand, free knowledge is that part of God's knowledge which He knows by His knowledge of His own will, both His desires and what He will, in fact, do. The content of this knowledge is made up of truths which refer to things which actually exist or has existed or will exist. They are knowledge of things which depend on God's decisions and actions. While natural knowledge is prevolitional, free knowledge is postvolitional since it depends on God's decision to create or act. The content of free knowledge is contingent because it could have been different from what it is. It includes only metaphysically contingent truths or truths which could have been prevented by God if He wanted (Internet encyclopedia, n.d.). Now middle knowledge is like natural knowledge because it is prevolitional or prior to God's decision to create. Yet it is not the same as natural knowledge because, like free knowledge, its content is contingent. The doctrine of middle knowledge could be encapsulated, thus: God has knowledge of metaphysically necessary states of affairs via natural knowledge, of what He intends to do via free knowledge, and in addition, of what free creatures would do if they were instantiated (via middle knowledge) (Internet Encyclopedia of Philosophy, n.d.). Hence, the content of middle knowledge refers to what would be the case if a different state of affairs were to obtain.

\section{Critique of Middle Knowledge}

Between God's natural knowledge and free knowledge, we have His middle knowledge and this is unique to Molinism. It is also through His middle knowledge that He knows conditional future contingents which are also known as counterfactuals of creaturely freedom. As we mentioned in the preceding section, counterfactuals are propositions which indicate what effects, 'would in fact be produced, remotely or immediately, by indeterministic secondary causes under a condition or hypothesis that specifies a possible spatio - temporal arrangement of secondary causes (Freddoso, 1988). In other words, counterfactuals of creaturely freedom (CFF) refer to what God could create in any possible world given the secondary causes included in each possible world (Nathan Justice, 2017).

Middle knowledge has been criticized from a Biblical view point. It is the notion of some scholars that middle knowledge can be refuted from an exegetical and hermeneutical approach (Charles J.R., 2019). This view is supported by scholars who seek or focus on biblical evidence for counterfactuals of freedom. But defenders of counterfactuals of freedom have always cited some passages to support their view. Such passages, for instance, are I Samuel 23:6-13, Matthew 11:20-24. In the Samuel's account, David was told that Saul and his great army would besiege Keilah and capture David and his men. On hearing this, David enquires from God if Saul would besiege Keilah and the answer was in the affirmative. David further enquired if the men of Keilah would hand him over to Saul, and the answer was also in the affirmative. Then David and his men ran away from Keilah. The account raises some questions. Why did God answer in the affirmative to both questions when actually Saul did not besiege Keilah and David was not captured? Those who object to divine foreknowledge use this argument against the proponents of counterfactuals of freedom. But rather than use it against counterfactuals, Nathan Justice (2017) maintains that the account supports God's foreknowledge of counterfactuals, for if David had remained in Keilah until Saul arrived, the men of Keilah would have delivered him to Saul. Further, Jesus displays knowledge of counterfactuals when he chided Chorazin and Bethsaida saying, 'Woe to Chorazin! Woe to you, Bethsaida! For if the miracles done in you were done in Tyre and Sidon, they would have repented long ago in sackcloth' (Matthew 11:21). Proponents of middle knowledge argue that without knowledge of counterfactuals, Jesus could not honestly make this statement.

Another argument against counterfactuals of freedom comes from the theological perspective. Nathan Justice (2017) admits that Molinism cannot be proven directly from the scripture since the notion of middle knowledge requires counterfactuals to be known prevolitionally, and this is not mentioned by any passage of scripture. That is, middle knowledge is a philosophically derived concept rather than from the scripture. This is why Charles J. Rennie (2019) contends that advocates of middle knowledge fail to ground it on the Bible. The passages cited by Molinists to support their view of counterfactuals have been objected by some scholars arguing that the passages are only rhetorical, and that God or Jesus is using the subjunctive mode to emphasize the point He wasmaking (Nathan Justice, 2017). But the Molinists place the burden of proof that those passages are rhetorical on the skeptic. Further, the Thomists raise three theological objections to Molinism. One such objection focuses on the asymmetry thesis, which states that God relates to good and evil in two different ways. The way the asymmetry thesis is understood is through the intention/permission distinction. The intention/permission distinction holds that God intends good to happen but permits evil to occur. Based on this distinction, the Thomists argue that 'God's total causal contribution to free actions is no determiningand hence the very same causal influence on God's part may result indifferently in either a good act or an evil act (Freddoso, 1988). In their view, without this intention/permission distinction, God could be considered the author of both good and evil in the world. 
Molina's response is that God concurrently upholds secondary causes by directly acting on the effect itself, in contrast to Baezian position that God acted directly on the secondary agent (Freddoso, 1988).

This is in response to the traditional Christian notion that God's general causal influence is required in order for secondary causes to bring about a kind of effect in the created world. And this cooperation with secondary causes is known as general concurrence. But Molina argues that God's concurrence is usually neutral and only rendered efficacious by the secondary causes. Molina, therefore, grounds the intention/permission distinction on God's grace, rather than in God's concurrence. He thinks that grace is a particular cause in contrast to the general causation of divine concurrence. This divine or God's concurrence is conceived as the cooperation with secondary causes. The Thomists give a second objection to Molinism which invokes the principle of predilection. The principle of predilection states that no one would be better than another person unless he were loved and helped more by God (Nathan Justice, 2017). This objection maintains that Molinism violates this principle, since two persons could be placed in the same circumstances and they would act differently, with the result that the one person may boast of his ability to accept and use God's grace. But Molinists contend that this argument does not hold sway since it is God who gratuitously singles one person out by arranging the circumstances in such a way that the individual freely acts. This is why He permits Peter to deny Him and Judas to betray Him by allowing them through His middle knowledge to be situated in situations in which they freely act. Therefore, in line with the Molinist's idea, God is still giving more grace to one individual than the other.

The third theological objection involves petitionary prayer. Prayers are sometimes offered for individuals to change their ways. But how can one reconcile strong providential control with libertarian freedom on the assumption of Molinism, especially as libertarian freedom maintains that one agent cannot determine another agent's actions; for if God cannot bring about changes in people's lives, He cannot answer prayers and by consequence Molinism diminishes the importance of prayer. The Molinists have responded to this objection. According to them, some aspects of conversion are the result of God's direct causation like when He said He would remove the heart of stone and replace it with the heart of flesh (Ezekiel 36:26). There is also the situation where God allows man to choose. On this basis, Molinists accept that God has direct causal influence over man's actions while at the same time holding on to libertarian freedom. Another response is that which distinguishes between strong actualization and weak actualization. In strong actualization, God directly causes the action to occur while in weak actualization, He brings about the states of affairs which result from His direct causation of something else (Nathan Justice, 2017). Accordingly, whatever happens in conversion and sanctification that does not involve human freewill, may be the result of God's strong actualization, and whatever happens in conversion and sanctification that involves human freewill may be the result of God's weak actualization.

\section{Resolving the Dichotomy between Counterfactuals of Creaturely Freedom and Determinism}

When Molina introduced the notion of middle knowledge, he provided a way to ground God's complete and infallible knowledge in His own decree without violating the freedom of creatures. It is argued in some quarters that middle knowledge is deterministic and therefore, the counterfactuals do not refer to free actions of creatures. The first argument is that of non - risk factor argument. This argument holds that since God has comprehensive knowledge of the future when combined with His free knowledge and of how creatures would exercise their freewill when making decisions, and since God uses that knowledge to actualize the kind of world He desires, then, God takes no risk at all. He providentially controls the whole universe. If this is the case, then, Moilinism removes freedom from creatures. Therefore, Molinism is deterministic. The second argument is that individuals have not the power to bring about the truth or falsity of the counterfactuals because they are true irrespective of what the individual actually does. The third argument is that since God's knowledge of counterfactuals of creaturely freedom informs His decision about which possible world to actualize, that knowledge and the true counterfactuals are part of the causal history of the actual world and therefore, are part of the fixed past. This is very essential to human freedom because freedom requires that the individual has the ability to act in a particular way or not to act in a particular way. Addressing the first poser, Molinists argue that the question is based on the assumed incompatibility between risks and creaturely freedom which is not necessarily so (internet Encyclopedia, n.d.). They argue that there is no guarantee that the removal of risks is incompatible with creaturely freewill. To the second poser that borders on the removal of ability to bring about the truth or falsity of counterfactuals, the Molinists contend that the individual had the ability to act otherwise in the past which would have brought about a different past. Finally, they reject the view that events which have causal consequences in the past are hard facts about the past. For them, the agent has the power to bring about a different past. For Charles J. Rennie (2019),by freely ordaining a particular world with a particular set of circumstances in which God foresees what the creature would freely do, the integrity of both divine agency and human agency are preserved. Therefore, middle knowledge reconciles the sovereignty of divine agency and the liberty of human agency by inserting a logical moment between God's natural knowledge and visionary knowledge, wherein God purportedly knows what every creature would freely do in any set of circumstances.

\section{Evaluation and Conclusion}

The most prominent objection to Molinism is the 'grounding objection' which argues that counterfactuals of freedom lack metaphysical grounds and therefore cannot be true or false, meaning that God cannot know them. This is why it is argued that the only plausible metaphysical grounding of counterfactuals is the intentions, desires and character of the person mentioned in the counterfactual. Hence, it is probable that a thing would occur or not occur and this fails to meet the Molinists' criteria that a thing would in fact occur. But this assumption is not true. Molinists' counterfactuals have metaphysical grounding like the grounding of absolute future contingents. For instance, a realist about the absolute future holds that a future - tense proposition has proper metaphysical grounds now if 'there will be at some future time adequate metaphysical grounds for the truth of its present - tense counterpart p.' In other words, all that is necessary to 
metaphysically ground a future - tense proposition is that 'some agent has caused or will cause the corresponding present - tense propositions to be true. Therefore, Molinists' counterfactuals could be grounded in a similar way. It seems appropriate to assume that there are now adequate metaphysical grounds for the truth of a conditional future contingent $F^{\prime}(p)$ on $\mathrm{H}$ just in case there would be adequate metaphysical grounds $(t)$ for the truth of the present -tense proposition $\mathrm{p}$ on the condition that $\mathrm{H}$ should obtain at t' (Nathan Justice, 2017).

It is the view of the Molinists that God knows what the decisions and actions of an agent would be because He comprehends even the incomprehensible with an incomprehensible comprehension. He knows certainly what is in itself uncertain. And this derives from the depth and unlimited perfection of His divine intellect. And this knowledge of counterfactuals is not inconsistent with human freewill. It rather helps Him (God) not to violate human freewill. For instance, God knew that Saul the first King of Israel would disobey his instructions. He even knew the kind of ruler he would be. When the Israelites requested for a king so that they would be like other nations, God explicitly told Samuel:

Now therefore, hearken unto their voice: howbeit yet protest solemnly to them, and show them the manner of the king that shall reign over them. And Samuel told the words of the Lord to the people that asked him of a king (I Samuel 8:9-10, KJV).

God's knowledge of all possible worlds and all possible situations in which His creatures would act enables Him to allow the best possible experiences that achieve His ultimate purpose without violating man's will. This is evident in the mission He gave Saul to go and destroy the Amalekites. As an agent, Saul used his initiative to do what he felt was good for the Lord. God did not interfere with his freewill. But suffice it to reiterate that God was aware of what he would do. When Saul failed, He only expressed his disappointment over Saul's inability to use his freedom aright. Not that He did not know.This, again shows clearly that God counts so much on human freedom.

Both Arminianism and Molinism, at their core agree that God possesses divine foreknowledge. But they differ in their view of the providential control of the universe. For Arminians, divine foreknowledge is sufficient enough for God's providential control of the world and the coherent conjunction of God's sovereignty and human responsibility. But for Molinists, divine foreknowledge alone cannot support God's providential control since it eliminates God's ability to deliberate between options. Molinism establishes a basis for strong providential control through its affirmation of divine foreknowledge and its insistence on the coherence between God's sovereignty and human responsibility.

From the foregoing, it is preponderant that Molinism provides a coherent view of divine providence. Since God knows what any person would in fact do in any set of circumstances, He may order the world to meet His goals and purposes without violating human freewill and responsibility. Also, Molinism provides a rational explanation of prophecy that involves middle knowledge and at the same time maintaining the freedom of the person performing the action. That is, He can have complete certainty about the actual occurrence of the action prophesied due to His providential guidance via middle knowledge while maintaining the freedom of the person being prophesied. This is because He knows certainly what is itself uncertain and therefore, knows whether or not Aristotle would have founded the Lyceum if he were not a student of Plato.

\section{References}

i. Adams, R.M. (2014). An Objection to Middle Knowledge. In Michael, P., William, H., Reinchenbach, B., David, B. (Eds.). Philosophy of Religion: Selected readings. New York: Oxford University Press.

ii. Basinger, D. (2014). Middle Knowledge and Classical Christian Thought. In Michael, P., William, H., Reinchenbach, B., David, B. (Eds.). Philosophy of Religion: Selected readings. New York: Oxford University Press.

iii. Charles, J.R. (2019). Is Middle Knowledge Biblical? Https://www.academics/edu/Documents.

iv. Fredosso, A.J. (1988). Introduction. In Alfred J. Fredosso (Ed

v. .) On Divine Foreknowledge. Ithaca: Cornell University Press.

vi. Internet Encyclopedia of Philosophy (n.d.). Middle Knowledge. Https://iep.utm.edu.

vii. Nathan, J. (2017). Aminianism and Molinisn on Divine Foreknowledge. A Senior Thesis submitted in partial fulfillment of the requirements for graduation in the Honours Program, Liberty University.

viii. Omoregbe, J. (2011a). Metaphysicsa without tears: Lagos, Nigeria: Joja Educational press Ltd.

ix. Omoregbe, J. (2011b). A simplified history of western philosophy. Lagos, Nigeria:Joja Educational press Ltd.

x. The King James Version

xi. Uduigwomen, A. F. \&Ozumba, G.O. (2005). A Concise introduction to Philosophy and logic. Nigeria: Century publishers.

xii. Vanarragon, R.J.. (2010). Key terms in Philosophy of Religion. New York: Continuity international Publishing group. 